\title{
The Long-Term Effect of Biochar on Soil Microbial Abundance, Activity and Community Structure Is Overwritten by Land Management
}

\section{OPEN ACCESS}

Edited by:

Hannes Schmidt,

University of Vienna, Austria

Reviewed by:

Carsten W. Mueller,

Technical University of

Munich, Germany

Anne Daebeler,

University of Vienna, Austria

*Correspondence:

Brieuc Hardy

b.hardy@cra.wallonie.be

Specialty section:

This article was submitted to

Soil Processes,

a section of the journal

Frontiers in Environmental Science

Received: 02 December 2018 Accepted: 25 June 2019

Published: 12 July 2019

Citation:

Hardy B, Sleutel S, Dufey JE and Cornelis J-T (2019) The Long-Term

Effect of Biochar on Soil Microbial Abundance, Activity and Community Structure Is Overwritten by Land Management.

Front. Environ. Sci. 7:110 doi: 10.3389/fenvs.2019.00110

\begin{abstract}
Brieuc Hardy ${ }^{1,2 *}$, Steven Sleutel ${ }^{3}$, Joseph E. Dufey ${ }^{1}$ and Jean-Thomas Cornelis ${ }^{4}$
${ }^{1}$ Earth and Life Institute-Environmental Sciences, Université Catholique de Louvain, Louvain-la-Neuve, Belgium, ${ }^{2}$ Département Agriculture et Milieu Naturel-Unité Fertilité des Sols et Protection des Eaux, Centre Wallon de Recherches Agronomiques, Gembloux, Belgium, ${ }^{3}$ Department of Environment, Faculty of Bioscience Engineering, Ghent University, Ghent, Belgium, ${ }^{4}$ TERRA Teaching and Research Centre, Gembloux Agro-Bio Tech (GXABT), University of Liège (ULiège), Gembloux, Belgium
\end{abstract}

Soil amendment with biochar can modify soil microbial abundance, activity and community structure. Nevertheless, the long-term evolution of these effects is unknown and of critical importance because biochar persists in soil for centuries. We selected nine charcoal kiln sites (CKS) from forests (four sites) and croplands (five sites) and determined the microbial properties of their topsoil, largely enriched with charcoal for $>150$ years. Adjacent soils were used as references unaffected by charcoal production. Soils were incubated in controlled conditions and emissions of $\mathrm{CO}_{2}$ were measured for 138 days. At day 68, an aliquot was sampled from each soil to determine microbial abundance and community structure by phospholipid fatty acid (PLFA) analysis. Before the extraction, one standard PLFA (C21:0 PC) was added to the soil to test the influence of charcoal on PLFAs recovery. The content of uncharred SOC and $\mathrm{pH}$ explained a main part of the variance of soil $\mathrm{CO}_{2}$ emissions, which supports the view that charcoal had a limited effect on soil respiration. The recovery of C21:0 PC was increased in presence of aged charcoal, which contrasts with the decreased recovery recorded shortly after biochar application. This underlines that properties of charcoal evolve dramatically over time, and that a long-term vision is critical in the perspective of amending soils with biochar. Land-use had an overriding control on the microbial community structure, surpassing the effect of a vast amount of charcoal present in the soil. In forests, 10 PLFAs from gram positive and general bacteria were significantly different between CKS and adjacent reference soils, whereas in croplands only four PLFAs from fungi, gram negative bacteria and actinomycetes were significantly affected. These results suggest that the long-term effect of charcoal on soil microbiota is overwritten by management practices. Biochar properties must therefore be regarded altogether with soil conditions to correctly design a successful soil amendment with biochar. Additionally, the absence of a relationship between individual PLFAs and charcoal-C supports the idea that the long-term effect of charcoal is related to a modification of soil ecological niche (e.g., nutrient availability, $\mathrm{pH}$ ) rather than to an alteration of the source of organic $\mathrm{C}$ available to biota.

Keywords: preindustrial charcoal kiln sites, historical charcoal hearths, black carbon, aged biochar, soil respiration, phospholipid fatty acids (PLFA), black carbon quantification, land use 


\section{INTRODUCTION}

Biochar application to soil is a carbon negative technology used to tackle climate change while sustainably improving soil fertility (Lehmann et al., 2006). There is a general agreement that the low degradability of biochar, like other types of black carbon (BC), derives mainly from its specific chemistry, which is dominated by fused aromatic ring structures (Haumaier and Zech, 1995; Glaser et al., 2000; Brodowski et al., 2005). Despite its intrinsic low biodegradability, the introduction of biochar to soil does often result in an increase in $\mathrm{CO}_{2}$ emissions in the short-term (Sagrilo et al., 2014). Among explanatory factors, the positive priming of biochar on the decomposition of native soil organic matter (SOM) (Maestrini et al., 2014) and the abiotic release of $\mathrm{CO}_{2}$ from the reaction of carbonates in the biochar after amendment to acidic soil (Bruun et al., 2014) were identified. Nevertheless, the main source of the increase in $\mathrm{CO}_{2}$ emissions from a biochar amended soil seems to be the microbially mediated decomposition of labile biochar constituents (e.g., Cross and Sohi, 2011; Hilscher and Knicker, 2011). In a meta-analysis of 46 studies, Sagrilo et al. (2014) showed that large additions of biochar to soil considerably increased $\mathrm{CO}_{2}$ emissions, whereas a low input of biochar relative to native soil organic carbon (SOC) content did not significantly affect emissions. Fabbri et al. (2012) related the mineralization rates of 20 biochars to their chemical composition and found biochars with higher concentrations of proteins and sugars (from incomplete transformation by pyrolysis) to be associated with the largest mineralization rates. In contrast, biochars produced at a higher temperature resulted in lower $\mathrm{CO}_{2}$ emissions (Fabbri et al., 2012), probably related to an increasing degree of aromaticity and aromatic condensation (Keiluweit et al., 2010; Wiedemeier et al., 2015) and the relative decrease of the labile fraction of biochar. Accordingly, biochar application has contrasting effects on soil biology depending on its amount and quality as well as initial soil properties (Lehmann et al., 2011).

Overall, the net increase in $\mathrm{CO}_{2}$ release following the application of biochar to soil appears to be a short-lived effect, while for incubations over a longer time period (>200 days), the average emission of $\mathrm{CO}_{2}$ is usually not or even negatively affected for large application rates (Sagrilo et al., 2014). To explain this result, Sagrilo et al. (2014) proposed that a major part of the labile fraction of biochar might have been consumed over 200 days. Another possible explanation is that $\mathrm{N}$ deficiency eventually occurs after prolonged incubation of biochar amended soil (Ameloot et al., 2015), as most biochars have high C:N ratios. In their survey, Sagrilo et al. (2014) showed that soils with a $\mathrm{C}: \mathrm{N}$ ratio $<10$ were much more subject to an increase in $\mathrm{CO}_{2}$ emissions after addition of biochar, which corroborates this assumption.

Despite an already overwhelming number of studies on the effect of biochar on soil biology and greenhouse gas emissions, most data originate from short-term experiments in laboratory conditions (Sagrilo et al., 2014). Insights in the long-term effects of biochar remain lacking (Maestrini et al., 2014; Sagrilo et al.,

Abbreviations: CKS, Charcoal kiln site; LU, Land use; K/R, Kiln vs. reference soil.
2014), although biochar persists in soil for centuries (Singh et al., 2012) and therein lies exactly its premise to abate net $\mathrm{CO}_{2}$ emission. Since properties of biochar change over time (Joseph et al., 2010), long-term implications of biochar soil amendment are very likely to differ from short-term effects. For instance, positive priming has only been observed shortly after addition of fresh biochar to soil and does not seem to last over long periods of time (Hamer et al., 2004; Wardle et al., 2008; Zimmerman et al., 2011). More importantly, on long timescales after the addition of biochar to soil, a decrease of metabolic quotient (defined as microbial activity reported to soil biomass) or even a lower absolute amount of respired $\mathrm{C}$ was observed in $\mathrm{BC}$ rich terra preta soils (Jin, 2010; Liang et al., 2010). Nevertheless, data from the Amazonia cannot be extrapolated to other soil and climate conditions with very different land-use histories. Additionally, several types of organic and inorganic household wastes other than biochar were involved in the genesis of terra preta soils (Glaser, 2007), which makes it nearly impossible to isolate the effect of biochar from the effect of these other inputs.

Worldwide, many sites can be found where biomass-derived black carbon was deposited centuries ago during charcoal production. Among historical charcoal deposits, pre-industrial charcoal kiln sites (CKS), also referred to as "historical charcoal hearths," have the potential to be used as a proxy for the long-term effect of biochar additions on soil properties. Particularly, CKS in deforested areas that converted to croplands present themselves as a natural long-term field experiment with replications of biochar application in agricultural soil (Hardy et al., 2017a; Kerré et al., 2017). As biochar application is mainly intended to cropland soils, these sites represent a critical source of information to unravel the long-term fate of biochar in soil and its effect on soil properties.

Very few studies have studied carbon turnover and soil biology at historic charcoal kiln sites in comparison with adjacent charcoal-free soils. Kerré et al. (2017) measured a smaller total of $\mathrm{CO}_{2}$ emissions from CKS soil than in adjacent reference soils and a smaller mineralization of fresh maize SOM (traced by ${ }^{13} \mathrm{C}$ isotopic signature) when added to a pre-industrial CKS soil. They related it to an increased sorption of dissolved organic carbon (DOC), with a preferential adsorption of the DOC rich in aromatics.

In this work, we aimed to assess long-term implications of charcoal enrichment at pre-industrial charcoal kiln sites on the soil microbial biomass, activity and community structure, with a special focus on the relationship between soil microbial activity and community structure and the contents of charcoal- $\mathrm{C}$ and uncharred SOC. We did so by relating laboratory-based $\mathrm{CO}_{2}$ emission measurements and phospholipid fatty acid (PLFA)based assessments of the microbial biomass and community structure to relative amounts of charcoal- $\mathrm{C}$ and of uncharred SOC in soil, determined by differential scanning calorimetry (DSC). Soil conditions may strongly interact with the impact of biochar on soil biological activity (e.g., Blackwell et al., 2010). Therefore, we specifically selected sites with contrasting land uses (forests and croplands) but with an otherwise comparable soil texture and mineralogy to infer to what extent land use interacts with the effect of charcoal on biological soil properties. 


\section{MATERIALS AND METHODS}

\section{Soil Samples}

The topsoil of nine pre-industrial CKS on Haplic or Albic Luvisol (IUSS Working Group WRB, 2014) located within the Belgian loess belt were sampled in April 2012. At the study sites, mean annual precipitations vary between 864 and $937 \mathrm{~mm}$, while mean annual temperature varies between 9.6 and $10^{\circ} \mathrm{C}$. According to the WRB classification, soil texture was defined as silt or silt loam (IUSS Working Group WRB, 2014). Four sites were located in forests (Hardy et al., 2016) and five in croplands (Hardy et al., 2017a), in areas that had been deforested for cultivation after charcoal production. Because the parent material (loess deposit) is identical in the nine sites, we assumed that land use was the main soil forming factor that differentiated cropland from forest sites. The sampled forest soils are all very acidic, even in presence of charcoal, which differs sharply from cropland soils that are frequently limed and had $\mathrm{pH}$ values close to neutral. For each site, soil properties of the organo-mineral (A) horizon of the CKS was compared to that of directly adjacent reference soil. For cropland sites, soil samples were taken to the depth of the plow layer (0$25 \mathrm{~cm}$ ) instead, similar to kiln and reference soils. For forest sites, the full depth of the A horizon was sampled, which is up 40$50 \mathrm{~cm}$ deep for charcoal-rich A horizons at CKS, whereas Ah horizons were limited to the top 5 to $10 \mathrm{~cm}$ for the reference soils.

\section{Soil Physico-Chemical Properties}

Soil $\mathrm{pH}$ was measured in water $\left(\mathrm{pH}-\mathrm{H}_{2} \mathrm{O}\right)$ and in $1 \mathrm{M} \mathrm{KCl}(\mathrm{pH}-$ $\mathrm{KCl}$ ) at a 1:5 soil:solution mass ratio. Elemental $\mathrm{C}$ and $\mathrm{N}$ contents were measured by dry combustion (vario MAX, Elementar). The inorganic $\mathrm{C}$ content was measured by the modified-pressure calcimeter method on finely ground subsamples $(<200 \mu \mathrm{m})$ (Sherrod et al., 2002). Inorganic $C$ content was always null or below the detection limit $\left(<0.2 \mathrm{~g} \mathrm{~kg}^{-1}\right)$. Therefore, total $\mathrm{C}$ was considered to correspond to total organic C (TOC), which includes charcoal-C. The potential CEC was determined by percolation of $1 \mathrm{M}$ ammonium acetate (naturally buffered at $\mathrm{pH}$ 7) on soil columns (Metson, 1956). Ammonium was desorbed with a $1.33 \mathrm{M} \mathrm{KCl}$ solution and measured by colorimetry (ISO7150/1). Exchangeable $\mathrm{Ca}^{2+}, \mathrm{Mg}^{2+}, \mathrm{K}^{+}$, and $\mathrm{Na}^{+}$were measured in the extract by inductively coupled plasma-atomic emission spectroscopy (ICP-AES 6500 duo, Thermo Scientific). We calculated the base saturation of the soil as the ratio between the sum of exchangeable $\mathrm{Ca}^{2+}, \mathrm{Mg}^{2+}, \mathrm{K}^{+}$, and $\mathrm{Na}^{+}$and the CEC. Plant-available $\mathrm{P}$ was extracted with a $0.5 \mathrm{M}$ ammonium acetate $-0.02 \mathrm{M}$ EDTA solution at $\mathrm{pH} 4.65$ at a $1: 5$ soil:solution mass ratio (Lakanen and Erviö, 1971), and extracts were analyzed by ICP-AES.

\section{Quantification of Charcoal-C Content}

Differential scanning calorimetry (DSC) was used to determine the contents of charcoal-C and uncharred SOC in soil. The methodology of charcoal-C quantification is detailed by Hardy et al. (2017a). Briefly, between 15 and $25 \mathrm{mg}$ of soil ground to powder were scanned with a DSC 100 (TA Instruments) under a flow of $50 \mathrm{ml} \mathrm{min}^{-1}$ synthetic air from room temperature to $600^{\circ} \mathrm{C}$, at a heating rate of $10^{\circ} \mathrm{C} \mathrm{min}^{-1}$ (Leifeld, 2007). The fraction of charcoal-C content was determined based on the height of three peaks derived from the combustion of charcoal relative to the main peak resulting from the combustion of uncharred organic matter (Leifeld, 2007). Prior to analysis, forest soils were buffered at $\mathrm{pH} 7$ by equilibration with $1 \mathrm{M}$ ammonium acetate (naturally buffered at $\mathrm{pH} 7$ ) and then saturated with $\mathrm{Ca}^{2+}$ by agitation in a solution of $1 \mathrm{M} \mathrm{CaCl}_{2}$. This pretreatment aimed to deprotonate most carboxylic acids present at the surface of charcoal, and to saturate carboxylate anions with $\mathrm{Ca}^{2+}$. Hardy et al. (2017b) showed that the presence of Ca decreases the thermal stability of the O-rich fraction of charcoal. This then prevents peaks from overlapping, which would otherwise bias the quantification of BC content. Agricultural soil samples were scanned without preliminary preparation because their $\mathrm{pH}-\mathrm{H}_{2} \mathrm{O}$ was already close to neutral, and because they were already nearly saturated with $\mathrm{Ca}^{2+}$ as they are limed frequently.

\section{Incubation Experiment}

For each sample, $120 \mathrm{~g}$ of dry soil sieved at $2 \mathrm{~mm}$ was weighed in steel cylinders of $100 \mathrm{~cm}^{3}$, closed by a porous nylon membrane on the bottom. Soil cores were saturated by the addition of demineralized water and were then left in a pressure pan until a $\mathrm{pF}$ of 2.5 was reached, approximately corresponding to field capacity for an undisturbed soil. Equilibration lasted 2 weeks. Each rewetted soil was then split into three subsamples of similar sizes that were incubated in hermetic jars of $500 \mathrm{ml}$ for 138 days in a climatic room, at a constant temperature of $20 \pm 1^{\circ} \mathrm{C}$. To follow $\mathrm{CO}_{2}$ emissions over time, an open recipient with $25 \mathrm{ml}$ of $0.5 \mathrm{M}$ $\mathrm{NaOH}$ was placed in the center of each jar, to trap $\mathrm{CO}_{2}$. Electrical conductivity (EC) of the $\mathrm{NaOH}$ solution decreases linearly with the amount of $\mathrm{CO}_{2}$ consumed and was measured after 3, 5, $10,17,24,31,38,45,52,61,68,75,90,97,115,124$, and 138 days to determine the amount of emitted $\mathrm{CO}_{2}$ from the soil (Rodella and Saboya, 1999). For each EC measurement, jars were left open to allow renewal of the headspace air. We calculated that $\mathrm{O}_{2}$ consumption between two measurements never exceeded $10 \%$ of the total volume of $\mathrm{O}_{2}$ in the jar, which guarantees that $\mathrm{O}_{2}$ was not deficient for microbial respiration. The incubations were stopped at 138 days because, at day 68, the pattern of $\mathrm{CO}_{2}$ emissions from the soil had reached a constant rate and an aliquot was sampled from each soil core for PLFA analysis.

\section{Microbial Biomass and Community Structure}

The aliquots from triplicates of the same soil were pooled together to limit the number of PLFA measurements to one for each soil. Directly after sampling from the incubation jars, soils were freeze-dried and stored at $-80^{\circ} \mathrm{C}$. During transport, freezedried samples were kept cold in dry ice. PLFA were extracted at the Department of Soil Management of Ghent University, according to the procedure described in detail by Sleutel et al. (2012), with the exception that we introduced a known amount of 1,2-dihenarachidoyl-sn-glycero-3-phosphocholine (C21:0 PC; Avanti Polar Lipids Inc.), a PLFA standard absent from soil, to test whether the presence of charcoal decreases the PLFA extraction efficiency, as it was observed for fresh biochars (Gomez et al., 2014). Thirty $\mu \mathrm{g}$ of C21:0 PC were added to each sample before 
the start of the PLFA extraction (Gomez et al., 2014). We assumed that charcoal interacts similarly with C21:0 PC and with PLFA naturally present in soil.

Briefly, $4 \mathrm{~g}$ of freeze-dried soil was mixed with $3.6 \mathrm{ml}$ phosphate buffer (pH 7.0), $4 \mathrm{ml}$ chloroform and $8 \mathrm{ml}$ methanol. After centrifugation, phospholipids in the solution of the supernatant were separated from neutral and glycolipids by sequential elution of chloroform and acetone on silica columns (Chromabond, Macherey-Nagel GmbH, Düren, Germany). Phospholipids were recuperated with methanol and saponified to obtain fatty acids. These were dried, dissolved in a methanol:toluene mixture and transformed into fatty acid methyl esters by methylation with $0.2 \mathrm{M}$ methanolic $\mathrm{KOH}$. The concentration of PLFA biomarkers was determined by gas chromatography-mass spectroscopy (GC-MS) with a Thermo Focus GC combined with a Thermo DSQ quadrupole MS (Interscience BVBA) in electron ionization mode. Soil PLFA concentrations provide quantitative information on total microbial biomass and microbial community structure. We considered that PLFAs iC15:0, aC15:0, iC16:0, iC17:0, and aC17:0 were representative for Gram-positive $(\mathrm{G}+)$ bacteria,

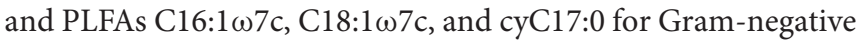
(G-) bacteria. PLFAs C15:0, C17:0, and cyC19:0 were considered as markers for general bacteria, and PLFAs 10MeC16:0 and $10 \mathrm{MeC} 18: 0$ as markers for actinomycetes. PLFAs C18:2 $\omega 6,9 \mathrm{c}$, $\mathrm{C} 18: 1 \omega 9 \mathrm{c}, \mathrm{C} 18: 2 \mathrm{c} 9,1$, and $\mathrm{C} 18: 3 \mathrm{c} 9,12,15$ were considered

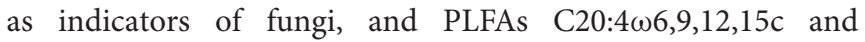
C20:5 $\omega 3,6,9,12,15 c$ of protozoa (Sleutel et al., 2012).

\section{STATISTICS AND DATA ANALYSIS}

\section{Soil Properties}

The complete set of soil properties was analyzed by permutational multivariate analysis of variance using the adonis function of the vegan R package (Oksanen et al., 2019) to test the effect of land use (LU, forest or cropland), CKS (K/R, kiln or reference site) and the interaction "LU $\times \mathrm{K} / \mathrm{R}$ " on soil properties. Data were analyzed in R 3.3.1 ( $\mathrm{R}$ Core Team, 2012).

\section{Metabolic Quotient}

The metabolic quotient $\left(q \mathrm{CO}_{2}\right)$ of soils was calculated as the ratio between daily emissions of $\mathrm{CO}_{2}$ and the total amount of PLFA in soil after 68 days of incubation.

\section{C-Mineralization Rates}

A double exponential model generally fits experimental data of carbon loss from soil incubated under controlled conditions well, and was often used to model $\mathrm{CO}_{2}$ fluxes from biochar, or from a biochar amended soil (e.g., Cheng et al., 2008; Hilscher and Knicker, 2011; Singh et al., 2012). Such model assumes the cumulatively emitted $\mathrm{C}, C_{\min }(t)\left(\mathrm{g} \mathrm{kg}^{-1}\right)$ at time $t(\mathrm{yr})$, to derive from two discrete pools of carbon in soil, one fast-cycling and one slow-cycling pool:

$$
C_{\min }(t)=X 1 \exp ^{-k 1 t}+X 2 \exp ^{-k 2 t}
$$

with $X 1$ being the fast-cycling pool of OC $\left(\mathrm{g} \mathrm{kg}^{-1}\right), k 1$ being the decay rate of $X 1\left(\mathrm{yr}^{-1}\right), X 2$ being the slow-cycling pool of OC (g $\left.\mathrm{kg}^{-1}\right)$ and $k 2$ being the decay rate of $X 2\left(\mathrm{yr}^{-1}\right)$. Carbon loss over the time of incubation was calculated by the difference between the initial SOC content and the cumulated amount of $\mathrm{CO}_{2}$ emitted. Equation (1) was fitted to the experimental cumulative $\mathrm{C}$ data in Matlab R2016a ( ${ }^{\circledR}$ MathWorks) by non-linear regression. Estimates of the half-life of both the fast-cycling and slow-cycling $\mathrm{C}$ pools are provided by $\ln (2) / K$.

\section{Microbial Community Structure}

To examine the relative composition of the microbial community in the different soil samples, PLFA concentrations were converted to percentages of the total PLFA concentration of the respective soil sample. The effect of $\mathrm{K} / \mathrm{R}, \mathrm{LU}$ and the interaction " $\mathrm{LU}$ $\times \mathrm{K} / \mathrm{R}$ " on soil microbial community structure was tested by permutational multivariate analysis of variance on the complete set of PLFA markers using the adonis function of the vegan $\mathrm{R}$ package (Oksanen et al., 2019). The soil microbial community structure was also explored by principal component analysis (PCA) in R 3.3.1 (R Core Team, 2012), with the package factoextra (Kassambara and Mundt, 2017). Only the 18 PLFAs most abundant at the scale of the dataset were kept in order to have a sufficient number of degrees of freedom to run the PCA. To explore the relationship between environmental variables and soil community structure, soil properties were fitted to the principal components of the PCA using the function envfit from vegan $\mathrm{R}$ package (Oksanen et al., 2019).

To further investigate possible differences between CKS and adjacent reference soils, all individual PLFAs were tested with bivariate paired $t$-tests, separately for cropland and forest soils. No correction of the $p$-value for repetitive testing was applied because methods that were tested (Boneferroni, Holm, and Benjamini-Hochberg) were too conservative, leading to insignificant results in 100 percent of cases.

\section{RESULTS}

Raw data is readily available as Supplementary Material. The dataset contains soil physico-chemical properties, results from the PLFA extraction and emissions of $\mathrm{CO}_{2}$ from the incubation experiment.

\section{Soil Properties}

The permutational multivariate analysis of variance detected a significant effect for both $\mathrm{K} / \mathrm{R}\left(\mathrm{r}^{2}=0.146, P<0.001\right)$ and $\mathrm{LU}$ $\left(\mathrm{r}^{2}=0.621, P<0.001\right)$ on soil properties, with a significant interaction $\mathrm{LU} \times \mathrm{K} / \mathrm{R}\left(\mathrm{r}^{2}=0.075, p=0.01\right)$. This underlines that the effect of CKS on soil properties depends on land use. Looking at soil properties individually, all of them differed $(P<$ $0.05)$ between forests and croplands except exchangeable $\mathrm{Mg}^{2+}$ (Table 1). Cropland soils contained less total OC, charcoal-C and uncharred SOC compared to forest soils. They also have a smaller C:N ratio and CEC. Cropland soils all had a $\mathrm{pH}$ close to neutral, which contrasts the very acidic forest soils. Accordingly, the exchange complex of cropland soils was saturated with 
TABLE 1 | Soil physico-chemical properties of kiln $(K)$ and reference $(R)$ soils from cropland and forest.

\begin{tabular}{|c|c|c|c|c|c|c|c|c|c|c|c|c|c|c|c|}
\hline Land use & $\begin{array}{l}\text { Depth } \\
\text { cm }\end{array}$ & Site & $K / \mathbf{R}$ & $\begin{array}{c}\text { Total OC } \\
\mathrm{g} \mathrm{kg}^{-1}\end{array}$ & $\begin{array}{l}\text { Char-C } \\
\mathrm{g} \mathrm{kg}^{-1}\end{array}$ & $\begin{array}{c}\text { Uncharred SOC } \\
\mathrm{g} \mathrm{kg}^{-1}\end{array}$ & $\begin{array}{c}\text { C:N } \\
-\end{array}$ & $\begin{array}{c}\text { CEC } \\
\mathrm{cmol}_{\mathrm{c}} \mathbf{k g}^{-1}\end{array}$ & $\begin{array}{l}\text { BS } \\
\%\end{array}$ & $\begin{array}{c}\mathrm{pH}_{\mathrm{H} 2 \mathrm{O}} \\
-\end{array}$ & $\begin{array}{c}\mathrm{pH}_{\mathrm{KCl}} \\
-\end{array}$ & $\begin{array}{c}\mathrm{Pav}_{\mathrm{av}} \\
\mathrm{mg} \mathrm{kg}^{-1}\end{array}$ & $\begin{array}{c}\mathrm{Ca}^{2+} \\
\mathrm{cmol}_{\mathrm{c}} \mathrm{kg}^{-1}\end{array}$ & $\begin{array}{c}\mathrm{Mg}^{2+} \\
\mathrm{cmol}_{\mathrm{c}} \mathrm{kg}^{-1}\end{array}$ & $\begin{array}{c}\mathrm{K}^{+} \\
\mathrm{cmol}_{\mathrm{c}} \mathrm{kg}^{-1}\end{array}$ \\
\hline \multirow[t]{12}{*}{ Cropland } & $0-25$ & 1 & $\mathrm{~K}$ & 38.4 & 18.3 & 20.1 & 18.0 & 21.5 & 100 & 5.80 & 5.10 & 41.8 & 19.9 & 2.60 & 0.38 \\
\hline & $0-25$ & & $\mathrm{R}$ & 15.5 & 1.4 & 14.1 & 10.9 & 12.8 & 100 & 6.10 & 5.90 & 54.3 & 13.5 & 2.29 & 0.47 \\
\hline & $0-25$ & 2 & $\mathrm{~K}$ & 31.1 & 16.2 & 14.9 & 15.8 & 13.4 & 99.1 & 6.10 & 5.40 & 23.8 & 11.4 & 1.38 & 0.40 \\
\hline & $0-25$ & & $\mathrm{R}$ & 14.1 & 1.9 & 12.2 & 12.0 & 9.6 & 94.9 & 6.10 & 5.40 & 28.6 & 7.5 & 1.15 & 0.40 \\
\hline & $0-25$ & 3 & $\mathrm{~K}$ & 34.7 & 16.3 & 18.4 & 17.5 & 16.8 & 93.0 & 6.56 & 5.73 & 5.71 & 13.9 & 0.16 & 1.52 \\
\hline & $0-25$ & & $\mathrm{R}$ & 16.4 & 1.2 & 15.2 & 11.2 & 10.9 & 100 & 6.85 & 5.78 & 4.47 & 9.4 & 0.15 & 1.54 \\
\hline & $0-25$ & 4 & $\mathrm{~K}$ & 20.6 & 7.0 & 13.6 & 15.0 & 12.4 & 100 & 7.56 & 7.05 & 93.23 & 14.3 & 0.47 & 1.32 \\
\hline & $0-25$ & & $\mathrm{R}$ & 12.1 & 0.3 & 11.8 & 11.0 & 9.9 & 100 & 7.39 & 6.64 & 72.36 & 9.5 & 0.47 & 1.16 \\
\hline & $0-25$ & 5 & $\mathrm{~K}$ & 26.7 & 9.0 & 17.7 & 16.2 & 15.7 & 100 & 8.09 & 7.50 & 103.88 & 22.2 & 0.55 & 0.58 \\
\hline & $0-25$ & & $\mathrm{R}$ & 11.4 & 0.5 & 10.9 & 11.6 & 10.0 & 100 & 8.29 & 7.79 & 110.70 & 20.5 & 0.53 & 0.56 \\
\hline & & Mean sd & $\mathrm{K}$ & 30.36 .9 & 13.45 .0 & 16.92 .6 & 16.51 .2 & 16.03 .6 & 98.43 .1 & 6.80 .9 & 6.21 .0 & 53.73 .0 & 16.34 .5 & 1.031 .0 & 0.840 .5 \\
\hline & & Mean sd & $\mathrm{R}$ & 13.92 .1 & 1.10 .7 & 12.81 .8 & 11.30 .5 & 10.61 .3 & 99.02 .3 & 6.90 .9 & 6.30 .9 & 54.10 .8 & 12.15 .2 & 0.920 .8 & 0.820 .5 \\
\hline \multirow[t]{10}{*}{ Forest } & $0-46$ & 6 & K & 96.1 & 61.5 & 34.6 & 24.4 & 29.5 & 5.2 & 4.0 & 3.3 & 12.9 & 1.11 & 0.18 & 0.17 \\
\hline & $0-6$ & & $\mathrm{R}$ & 69.7 & 4.5 & 65.2 & 15.6 & 17.9 & 15.8 & 3.4 & 3.0 & 161.8 & 2.00 & 0.50 & 0.27 \\
\hline & $0-59$ & 7 & $\mathrm{~K}$ & 93.0 & 73.8 & 19.2 & 27.2 & 33.6 & 28.6 & 5.0 & 3.8 & 14.1 & 8.53 & 0.76 & 0.16 \\
\hline & $0-10$ & & $\mathrm{R}$ & 79.3 & 0.0 & 79.3 & 15.8 & 20.0 & 12.0 & 3.9 & 3.1 & 130.6 & 1.47 & 0.43 & 0.42 \\
\hline & $0-45$ & 8 & K & 85.2 & 50.4 & 34.8 & 27.8 & 25.3 & 7.2 & 4.3 & 3.4 & 15.9 & 1.30 & 0.28 & 0.16 \\
\hline & $0-7$ & & $\mathrm{R}$ & 70.6 & 0.4 & 70.2 & 15.6 & 16.2 & 19.1 & 4.0 & 3.2 & 100.1 & 1.97 & 0.60 & 0.46 \\
\hline & $0-38$ & 9 & $\mathrm{~K}$ & 68.4 & 29.6 & 38.8 & 22.3 & 23.8 & 5.3 & 4.0 & 3.1 & 43.2 & 0.69 & 0.19 & 0.32 \\
\hline & $0-7$ & & $\mathrm{R}$ & 70.2 & 0.0 & 70.2 & 13.9 & 29.5 & 5.2 & 3.9 & 3.0 & 257.9 & 1.24 & 0.38 & 0.41 \\
\hline & & Mean sd & $\mathrm{K}$ & 85.712 .4 & 53.88 .7 & 31.88 .6 & 25.42 .6 & 28.14 .4 & 11.611 .4 & 4.30 .5 & 3.40 .3 & 21.54 .5 & 2.93 .7 & 0.350 .27 & 0.200 .07 \\
\hline & & Mean sd & $\mathrm{R}$ & 72.54 .6 & 1.22 .2 & 71.25 .9 & 15.20 .9 & 18.41 .7 & 14.53 .8 & 3.80 .3 & 3.10 .1 & 16368 & 1.70 .37 & 0.480 .09 & 0.390 .08 \\
\hline \multirow[t]{3}{*}{ ANOVA } & & LU & $P$-value & $<0.001$ & $<0.001$ & $<0.001$ & $<0.001$ & $<0.001$ & $<0.001$ & $<0.001$ & $<0.001$ & 0.097 & $<0.001$ & 0.11 & 0.01 \\
\hline & & $\mathrm{K} / \mathrm{R}$ & $P$-value & $<0.001$ & $<0.001$ & $<0.001$ & $<0.001$ & $<0.001$ & 0.49 & 0.65 & 0.86 & 0.01 & 0.14 & 0.98 & 0.69 \\
\hline & & $\mathrm{LU} \times \mathrm{K} / \mathrm{R}$ & $P$-value & 0.65 & $<0.001$ & $<0.001$ & 0.002 & 0.14 & 0.66 & 0.38 & 0.53 & 0.006 & 0.44 & 0.73 & 0.60 \\
\hline
\end{tabular}

Analysis of variance (ANOVA) was performed on the dataset to test the effect of land use (LU), kiln site (K/R) and their interaction (LU x K/R). P-values $<0.05$ are highlighted in gray. 
exchangeable "base" cations $\left(\mathrm{Ca}^{2+}, \mathrm{Mg}^{2+}, \mathrm{K}^{+}\right)$, whereas forest soils were very desaturated.

$\mathrm{K} / \mathrm{R}$ furthermore affected the contents of TOC, charcoal$\mathrm{C}$ and uncharred SOC, the C:N ratio and CEC. A significant interaction with LU existed for charcoal-C $(P<0.001)$ and uncharred SOC $(P<0.001)$ contents, the C:N ratio $(P=$ $0.002)$ and the concentration of available $\mathrm{P}(P=0.006)$, which indicates that the effect of $\mathrm{K} / \mathrm{R}$ on these properties depends on land use. The topsoil contents of total OC and charcoal-C were always larger at CKS than at adjacent reference sites regardless of land use, but the difference was larger in forest. Charcoal-C constituted about a third of total C in cropland soil and half of the total C in forest soil (Table 1). The soil C:N ratio and CEC were also systematically higher at CKS. In forest soils, uncharred SOC content was smaller at CKS than in adjacent reference soils, whereas it is slightly larger at CKS in cropland soils. The effect of CKS on the concentration of available $\mathrm{P}$ also strongly depended on land use. In croplands, CKS and reference soils have similar contents of available $\mathrm{P}$ and exchangeable $\mathrm{K}$, whereas these were significantly lower in forest CKS soils. In forest, CKS soils also have slightly higher $\mathrm{pH}_{\mathrm{H} 2 \mathrm{O}}$ and $\mathrm{pH}_{\mathrm{KCl}}$ values, whereas $\mathrm{pH}$ values are very similar to that of reference soils in croplands.

\section{C-Mineralization Rates, Microbial Abundance and Metabolic Quotient}

In croplands, the absolute cumulative $\mathrm{CO}_{2}$ emissions from CKS soil were similar to that from adjacent reference soils. In contrast, $\mathrm{CO}_{2}$ emissions from forest CKS soils were much smaller than that from adjacent reference soils (e.g., Figure 1A). If, however, $\mathrm{CO}_{2}$ emissions are expressed per unit of total $\mathrm{C}$, they are systematically smaller in CKS soil than in adjacent reference soil, regardless of land use (Figure 1B). Data of $\mathrm{C}$ loss from $\mathrm{CO}_{2}$ emissions were fitted with double exponential models, which consider the contribution of two pools of $\mathrm{C}$ to $\mathrm{CO}_{2}$ emissions, one fast-cycling and one slow-cycling. The models fitted the data particularly well $\left(R^{2}>0.999\right)$. In croplands, the fast-cycling C pool had a similar computed size and half-life in the CKS and the reference soil (Table 2). In contrast, the computed size of the fast-cycling pool in forests was about half of that in the reference soil, but both had comparable turnover. In croplands, the slow-cycling C pool in the CKS soils had an estimated mean half-life of 22.2 years, more than twice as long as the reference soils' half-life (9.9 years). The slow-cycling $\mathrm{C}$ pool of the forest CKS soils had a mean half-life of 61.3 years, again, about double that of the adjacent reference soils' slow $\mathrm{C}$ pool half-life (32.5 years).

Total PLFA biomass is strongly $(p<0.001)$ affected by LU, $\mathrm{K} / \mathrm{R}$ and the interaction $\mathrm{LU} \times \mathrm{K} / \mathrm{R}$. The overall amount of total PLFA is larger in forests than in croplands, whereas the effect of $\mathrm{K} / \mathrm{R}$ is antagonist depending on land use: in croplands, total PLFA biomass in CKS soils is larger than in adjacent reference soils but in forests it is much smaller than in adjacent reference soils. Statistical analysis did not detect significant effects of LU, $\mathrm{K} / \mathrm{R}$, or $\mathrm{LU} \times \mathrm{K} / \mathrm{R}$ for the $q \mathrm{CO}_{2}$.

\section{Microbial Biomass and Community Structure}

Recovery of standard PLFA C21:0 PC (added to the soil to test whether charcoal interferes with the extraction of individual PLFAs or not) from the soil was low (a few percent only), which suggests that its digestion during extraction was incomplete. The amount of C21:0 PC recovered from CKS soils was on average $43.6 \pm 45.9 \%$ larger $(P=0.012)$ than from reference soils.

The permutational multivariate analysis of variance resulted in a significant effect of LU $\left(r^{2}=0.686, P<0.001\right)$ but in a nonsignificant effect of $\mathrm{K} / \mathrm{R}\left(r^{2}=0.030, P=0.188\right)$ on the PLFA dataset. The $\mathrm{r}^{2}$ score calculated for the interaction $\mathrm{K} / \mathrm{R} \mathrm{x} \mathrm{LU}$ was $0.047(P=0.098)$.

The distribution of the proportion of PLFAs between the different treatments is illustrated by the principal component analysis (Figure 2). The first component of the PCA explains $53.6 \%$ of total variance in the dataset and discriminates wellbetween forest and cropland soils $\left(\mathrm{r}^{2}=0.91, P<0.001\right)$. The second axis explains 19\% of total variance, and best discriminates between CKS and reference soils $\left(\mathrm{r}^{2}=0.24, P\right.$ $=0.037)$. Scores of the fit of both PLFAs markers and soil properties on the first and second principal components of the PCA are presented in Table 3. Regarding PLFAs, all of them have a significant contribution to the determination of the first principal component (PC1) or the second (PC2) except the a C17.0 marker that is not significantly represented. PLFAs C16.0, C18.0, C18.1 $\omega 9 \mathrm{c}$, and C.17.0 are the markers best explained by PC2. From second principal component scores, it appears that the microbial community structure of CKS and reference soils differ more strongly in forests than in croplands. For forest soils, CKS have systematically smaller scores than reference sites in the second dimension of the PCA, whereas no systematic difference appears for cropland soils (Figure 2). As excepted for exchangeable $\mathrm{Na}(P=0.851)$ and $\mathrm{Mg}(P=0.083)$, the fit of soil properties on PC1 and PC2 resulted in significant squared correlation coefficients. TOC content, total $\mathrm{N}$ content, soil $\mathrm{pH}_{\mathrm{H} 2 \mathrm{O}}$ and $\mathrm{pH}_{\mathrm{KCl}}$, exchangeable $\mathrm{Ca}$ and base saturation are strongly (positively or negatively) correlated with $\mathrm{PC} 1$, whereas Charcoal-C, the C:N ratio, available $\mathrm{P}$ and exchangeable $\mathrm{Mg}$ and $\mathrm{Na}$ are strongly correlated to PC2 (Table 3 ).

Further investigation of the relative proportion of individual PLFAs on total soil microbial biomass allowed identifying the markers significantly $(P<0.1)$ affected by CKS for both land uses (Table 4). In croplands, the proportion of $10 \mathrm{MeC} 16$ (Actinomycetes) was larger in CKS than in reference soils whereas the proportion of C16:1c9 (G-), C16:1c11 (Arbuscular Mycorhizal Fungi, AMF) and C18:2c9,12 (saprotrophic fungi) was smaller. In forests, the proportions of iC14:0 (G+), aC16:0 (G+), C16:0 (general bacteria), iC17:0 (G+), aC17:0 (G+), C17:0 (general bacteria), C18:0 (general bacteria), and C24:1 $\omega 9$ (general eucaryotes) were larger in CKS than in reference soils, whereas the proportion of C14:0 (general bacteria), iC15:0 $(\mathrm{G}+)$ and iC16:0 $(\mathrm{G}+)$ was smaller. None of the PLFAs were significantly affected for both forest and cropland soils. Among PLFAs significantly affected in forests, strong relationships were found with $\mathrm{pH}_{\mathrm{H} 2 \mathrm{O}}(\mathrm{C} 14: 0$, iC15:0, iC16:0, aC16:0, C16:0, C17:0, and C18:0), exchangeable $\mathrm{Ca}$ 


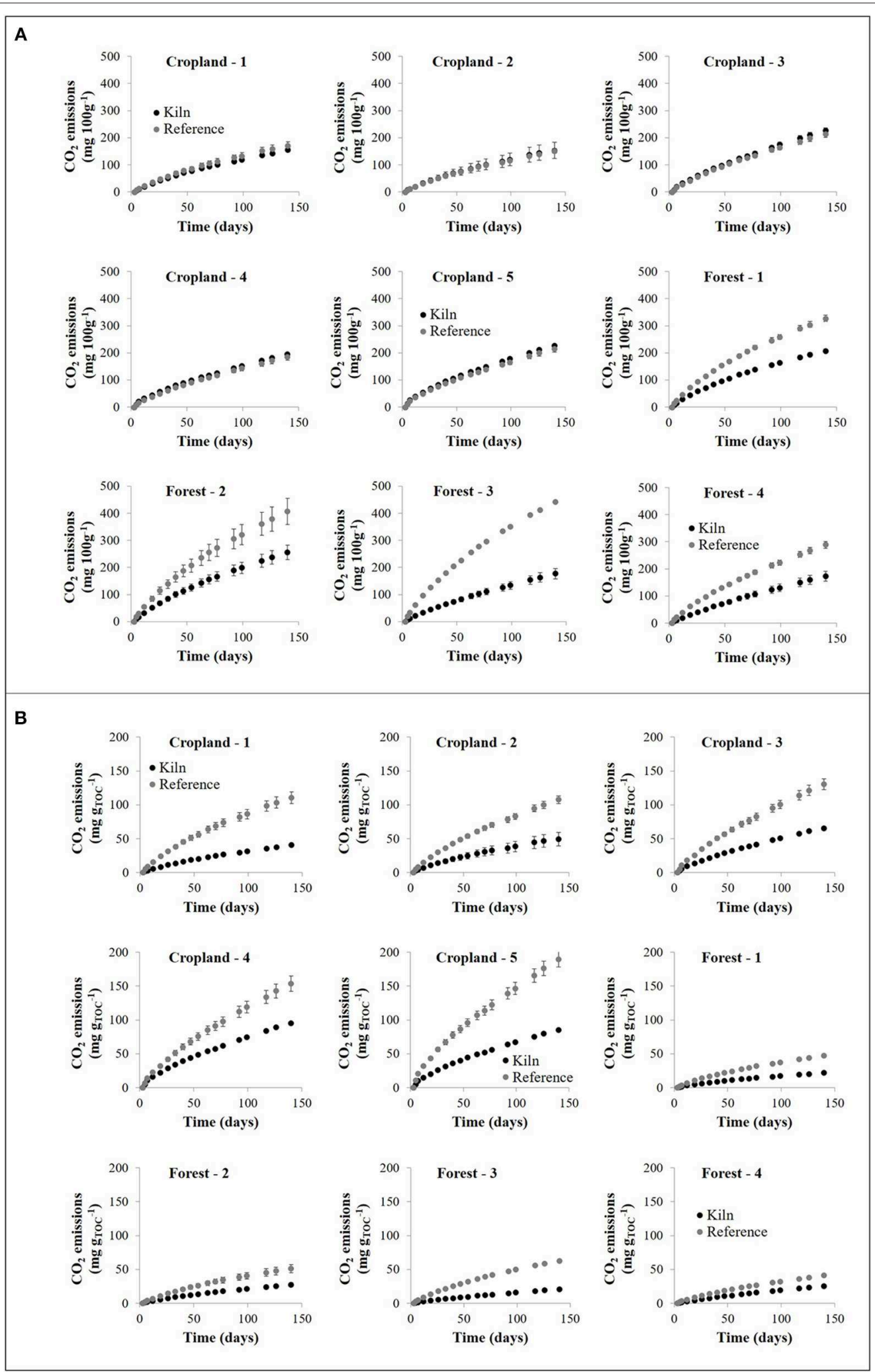

FIGURE 1 | Mean cumulative emissions of $\mathrm{CO}_{2}$ over time from kiln (K, black symbols) and reference (R, gray symbols) soils for the five study sites in cropland (circles) and the four study sites in forest (triangles). Error bars correspond to one standard deviation. (A) Emissions of $\mathrm{CO}_{2}$ per $100 \mathrm{~g}$ of dry soil; (B) Emissions of $\mathrm{CO}_{2}$ per $\mathrm{g}$ of total organic C (TOC). 
TABLE 2 | Total PLFA microbial biomass, metabolic quotient $\left(\mathrm{qCO}_{2}\right)$ at day 68 of incubation and parameters of the double exponential models fitted to data of total C loss by $\mathrm{CO}_{2}$ emissions from kiln $(\mathrm{K})$ and reference $(\mathrm{R})$ soils from cropland and forest during the 138 days incubation experiment.

\begin{tabular}{|c|c|c|c|c|c|c|c|c|}
\hline \multirow[b]{2}{*}{ Land use } & \multirow[b]{2}{*}{ Site } & \multirow[b]{2}{*}{$K / R$} & \multirow[b]{2}{*}{$\begin{array}{c}\text { Total PLFA } \\
\mathrm{nmol} \mathrm{g}^{-1}\end{array}$} & \multirow[b]{2}{*}{$\begin{array}{c}q \mathrm{CO}_{2} \\
\mu \mathrm{gC} \mathrm{d}^{-1} \mathrm{nmol}^{-1}\end{array}$} & \multirow[b]{2}{*}{$\begin{array}{c}\mathrm{X} 1 \\
\mathrm{gC} \mathrm{kg} \mathrm{kg}^{-1}\end{array}$} & \multicolumn{2}{|c|}{ C-mineralization } & \multirow[b]{2}{*}{$\begin{array}{l}\text { Half-life } \\
\text { Yr }\end{array}$} \\
\hline & & & & & & $\begin{array}{c}\text { Half-life } \\
\text { Yr }\end{array}$ & $\begin{array}{c}\mathrm{X} 2 \\
\mathrm{gC} \mathrm{kg}\end{array}$ & \\
\hline \multirow[t]{12}{*}{ Cropland } & 1 & $\mathrm{~K}$ & 17.1 & 0.152 & 0.139 & 0.076 & 38.3 & 34.8 \\
\hline & & $\mathrm{R}$ & 16.8 & 0.178 & 0.166 & 0.077 & 15.3 & 13.0 \\
\hline & 2 & K & 15.6 & 0.179 & 0.154 & 0.087 & 31.0 & 29.7 \\
\hline & & $\mathrm{R}$ & 12.1 & 0.223 & 0.130 & 0.073 & 14.0 & 12.7 \\
\hline & 3 & $\mathrm{~K}$ & 25.2 & 0.147 & 0.138 & 0.059 & 34.6 & 18.6 \\
\hline & & $\mathrm{R}$ & 19.9 & 0.175 & 0.142 & 0.066 & 16.3 & 9.5 \\
\hline & 4 & K & 18.3 & 0.172 & 0.119 & 0.041 & 20.5 & 12.8 \\
\hline & & $\mathrm{R}$ & 16.1 & 0.187 & 0.116 & 0.057 & 12.0 & 7.9 \\
\hline & 5 & $\mathrm{~K}$ & 15.6 & 0.220 & 0.159 & 0.046 & 26.5 & 15.0 \\
\hline & & $\mathrm{R}$ & 18.4 & 0.183 & 0.126 & 0.040 & 11.3 & 6.3 \\
\hline & Mean sd & K & 18.44 .0 & 0.1740 .029 & 0.1420 .016 & 0.0620 .019 & 30.26 .9 & 22.29 .6 \\
\hline & Mean sd & $\mathrm{R}$ & 16.73 .0 & 0.1890 .019 & 0.1360 .019 & 0.0630 .015 & 13.82 .1 & 9.92 .9 \\
\hline \multirow[t]{10}{*}{ Forest } & 6 & $\mathrm{~K}$ & 27.8 & 0.130 & 0.231 & 0.085 & 95.9 & 72.0 \\
\hline & & $\mathrm{R}$ & 55.3 & 0.107 & 0.371 & 0.083 & 69.3 & 33.5 \\
\hline & 7 & $\mathrm{~K}$ & 15.7 & 0.288 & 0.290 & 0.101 & 92.7 & 56.5 \\
\hline & & $\mathrm{R}$ & 56.5 & 0.270 & 0.560 & 0.107 & 78.8 & 34.4 \\
\hline & 8 & $\mathrm{~K}$ & 20.8 & 0.151 & 0.111 & 0.075 & 85.1 & 59.6 \\
\hline & & $\mathrm{R}$ & 55.7 & 0.140 & 0.595 & 0.105 & 70.0 & 27.9 \\
\hline & 9 & K & 25.9 & 0.124 & 0.186 & 0.139 & 68.2 & 56.9 \\
\hline & & $\mathrm{R}$ & 49.2 & 0.102 & 0.257 & 0.078 & 70.0 & 34.1 \\
\hline & Mean sd & $\mathrm{K}$ & 22.55 .44 & 0.1730 .077 & 0.2040 .076 & 0.1440 .040 & 85.512 .4 & 61.37 .3 \\
\hline & Mean sd & $\mathrm{R}$ & 46.713 .8 & 0.1540 .078 & 0.4460 .157 & 0.1350 .021 & 72.04 .5 & 32.53 .1 \\
\hline \multirow[t]{3}{*}{ ANOVA } & LU & $P$-value & $<0.001$ & 0.99 & 0.019 & 0.80 & $<0.001$ & $<0.001$ \\
\hline & $\mathrm{K} / \mathrm{R}$ & $P$-value & $<0.001$ & 0.50 & $<0.001$ & 0.002 & $<0.001$ & $<0.001$ \\
\hline & $L U \times K / R$ & $P$-value & $<0.001$ & 0.53 & 0.007 & 0.70 & 0.68 & 0.02 \\
\hline
\end{tabular}

Analysis of variance (ANOVA) was performed on the dataset to test the effect of land use (LU), kiln site (K/R) and their interaction (LU $x$ K/R). P-values < 0.05 are highlighted in gray.

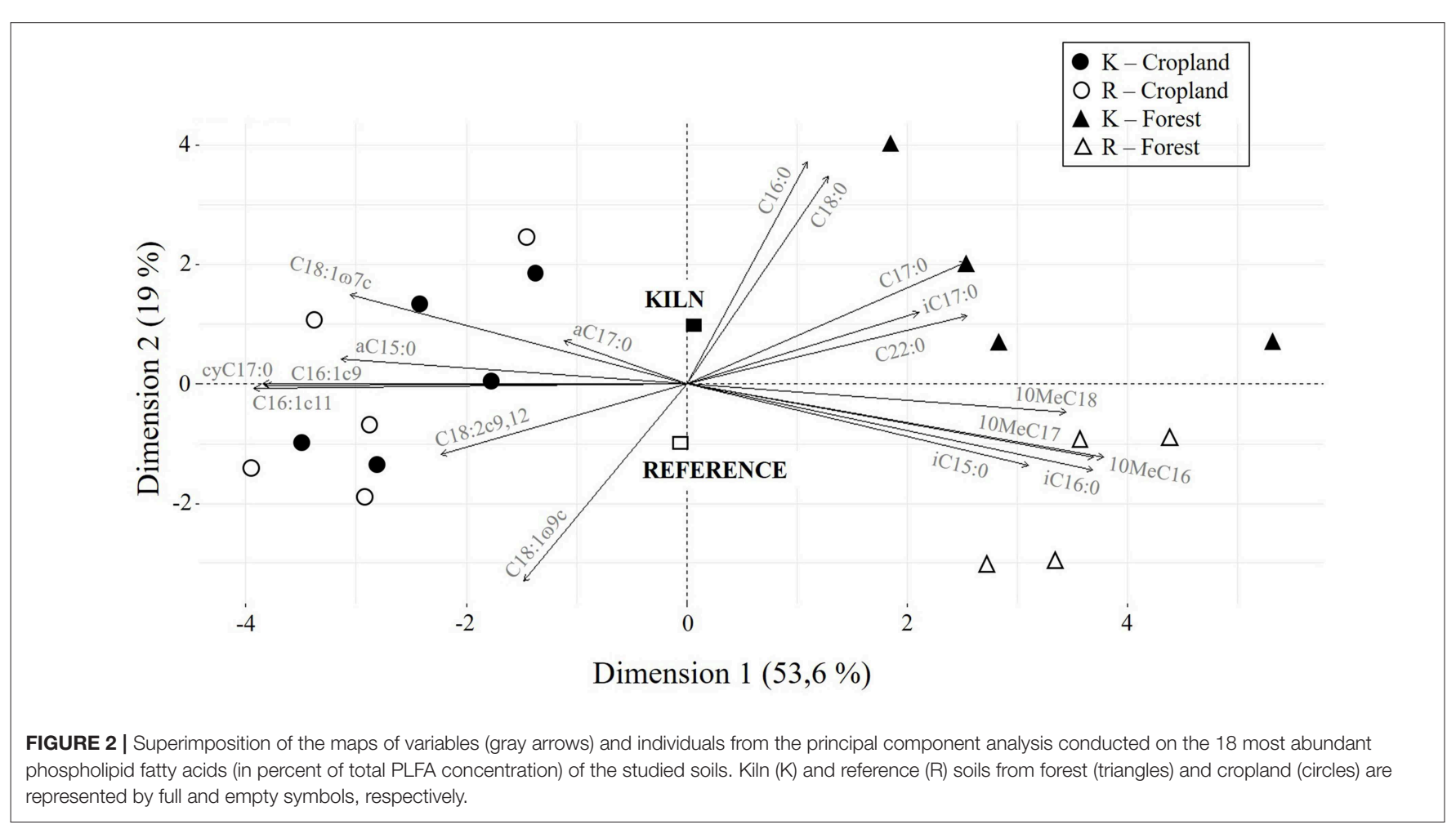


TABLE 3 | Scores of individual PLFAs and soil properties on the first and second components of the principal component analysis of PLFA's microbial community structure.

\begin{tabular}{|c|c|c|c|c|c|}
\hline PLFAs & PC1 & PC2 & $r^{2}$ & $\operatorname{Pr}(>r)$ & \\
\hline iC15.0 & 0.804 & 0.594 & 0.71 & 0.003 & $\star \star$ \\
\hline aC15.0 & -0.976 & -0.218 & 0.62 & 0.001 & 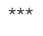 \\
\hline iC16.0 & 0.837 & 0.547 & 0.97 & 0.001 & 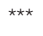 \\
\hline C16.0 & 0.172 & -0.985 & 0.93 & 0.001 & 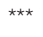 \\
\hline X10MeC16 & 0.873 & 0.487 & 0.94 & 0.001 & $* \star \star$ \\
\hline iC17.0 & 0.723 & -0.691 & 0.36 & 0.034 & * \\
\hline $\mathrm{aC} 17.0$ & -0.676 & -0.736 & 0.11 & 0.438 & \\
\hline C16.1c9 & -0.999 & -0.005 & 0.92 & 0.001 & 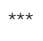 \\
\hline C16.1c11 & -0.999 & 0.032 & 0.96 & 0.001 & 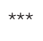 \\
\hline C17.0 & 0.595 & -0.804 & 0.65 & 0.002 & $\star \star$ \\
\hline X10Me17.0 & 0.879 & 0.476 & 0.98 & 0.001 & $\star \star \star ~$ \\
\hline cy17.0 & -0.999 & 0.012 & 0.91 & 0.001 & 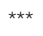 \\
\hline C18.0 & 0.214 & -0.976 & 0.85 & 0.001 & 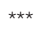 \\
\hline X10MeC18 & 0.975 & 0.220 & 0.75 & 0.001 & *** \\
\hline C18.1.w9c & -0.257 & 0.966 & 0.82 & 0.001 & *** \\
\hline C18.1.w7 & -0.773 & -0.634 & 0.72 & 0.001 & 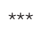 \\
\hline C18.2c9.12 & -0.748 & 0.664 & 0.39 & 0.020 & * \\
\hline $\mathrm{C} 22.0$ & 0.799 & -0.600 & 0.48 & 0.008 & $\star \star$ \\
\hline \multicolumn{6}{|l|}{ SOIL PROPERTIES } \\
\hline $\mathrm{OC}$ & 0.961 & -0.276 & 0.80 & 0.001 & 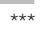 \\
\hline Charcoal-C & 0.298 & -0.954 & 0.60 & 0.001 & 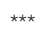 \\
\hline Uncharred SOC & 0.716 & 0.698 & 0.87 & 0.001 & *** \\
\hline Ntot & 0.947 & 0.322 & 0.83 & 0.001 & 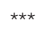 \\
\hline C:N ratio & 0.556 & -0.831 & 0.55 & 0.003 & $\star \star$ \\
\hline $\mathrm{pH}_{\mathrm{H} 2 \mathrm{O}}$ & -0.989 & 0.146 & 0.88 & 0.001 & 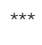 \\
\hline $\mathrm{pH}_{\mathrm{KCl}}$ & -0.982 & 0.187 & 0.90 & 0.001 & 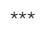 \\
\hline Available P & 0.298 & 0.954 & 0.42 & 0.013 & * \\
\hline Exchangeable Ca & -0.996 & -0.087 & 0.78 & 0.001 & $\star \star \star \star ~$ \\
\hline Exchangeable Mg & -0.545 & -0.839 & 0.28 & 0.083 & \\
\hline Exchangeable K & -0.659 & 0.752 & 0.45 & 0.009 & $\star *$ \\
\hline Exchangeable $\mathrm{Na}$ & 0.120 & -0.993 & 0.02 & 0.851 & \\
\hline Cation exchange capacity & 0.644 & -0.765 & 0.64 & 0.002 & $\star \star$ \\
\hline Base saturation & -0.985 & 0.174 & 0.89 & 0.001 & 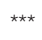 \\
\hline
\end{tabular}

Asterisks indicate the level of significance for each score ${ }^{* \star *} P \leq 0.001$; $\left.{ }^{\star \star} P \leq 0.01 ;{ }^{\star} P \leq 0.05\right)$.

(C14:0, iC15:0, iC16:0, aC16:0, C16:0, and C17:0), uncharred SOC concentration (C14:0, iC15:0, iC16:0, aC16:0, C16:0, and C18:0) and exchangeable $\mathrm{K}$ (iC17:0, C17:0). In contrast, no clear relationship was found with charcoal-C concentration for any of these PLFAs. For PLFAs significantly affected in croplands, no clear link was found with any investigated soil physico-chemical properties.

\section{DISCUSSION}

\section{The Effect of Charcoal on $\mathrm{CO}_{2}$ Mineralization, Soil Microbial Abundance and Metabolic Quotient}

The small rate of respiration per unit of TOC in CKS soils (Figure 1) and the nearly doubled turnover of the slow-cycling C pool compared to reference soils (Table 2) confirms the
TABLE 4 | Proportion of individual PLFAs on total soil biomass that are statistically different $(P<0.1)$ between charcoal kiln sites (CKS) and adjacent reference soils, according to pairwise $t$-tests.

\begin{tabular}{|c|c|c|c|c|c|}
\hline & \multirow[t]{2}{*}{ PLFA } & \multirow[t]{2}{*}{$\begin{array}{l}\text { Microbial } \\
\text { group }\end{array}$} & \multirow{2}{*}{$\begin{array}{c}\text { CKS soil } \\
\begin{array}{c}\text { Mean } \pm \text { s. d. } \\
\text { (\% mol })\end{array}\end{array}$} & \multirow{2}{*}{$\begin{array}{c}\begin{array}{c}\text { Reference } \\
\text { soil }\end{array} \\
\begin{array}{c}\text { Mean } \pm \text { s. d. } \\
(\% \mathrm{~mol})\end{array}\end{array}$} & \multirow[t]{2}{*}{$p$-value } \\
\hline & & & & & \\
\hline \multirow[t]{4}{*}{ Cropland } & $10 \mathrm{MeC} 16$ & Actinomycetes & $5.30 \pm 0.26$ & $4.71 \pm 0.39$ & 0.004 \\
\hline & C16:1c9 & $\begin{array}{l}\text { Gram negative } \\
\text { bact. }\end{array}$ & $9.64 \pm 1.60$ & $10.44 \pm 1.41$ & 0.01 \\
\hline & C16:1c11 & $\begin{array}{l}\text { Arbuscular } \\
\text { mycorrhizal } \\
\text { fungi }\end{array}$ & $5.42 \pm 0.69$ & $6.00 \pm 0.67$ & 0.05 \\
\hline & C18:2c9,12 & $\begin{array}{l}\text { saprotrophic } \\
\text { fungi }\end{array}$ & $2.31 \pm 0.24$ & $2.75 \pm 0.55$ & 0.07 \\
\hline \multirow[t]{11}{*}{ Forest } & iC14:0 & $\begin{array}{l}\text { Gram positive } \\
\text { bact. }\end{array}$ & $0.72 \pm 0.16$ & $0.43 \pm 0.07$ & 0.01 \\
\hline & C14:0 & General bact. & $0.58 \pm 0.16$ & $0.83 \pm 0.18$ & 0.02 \\
\hline & iC15:0 & $\begin{array}{l}\text { Gram positive } \\
\text { bact. }\end{array}$ & $6.16 \pm 1.51$ & $7.64 \pm 1.59$ & $<0.001$ \\
\hline & iC16:0 & $\begin{array}{l}\text { Gram positive } \\
\text { bact. }\end{array}$ & $7.52 \pm 2.51$ & $10.81 \pm 0.55$ & 0.07 \\
\hline & $\mathrm{aC} 16: 0$ & $\begin{array}{l}\text { Gram positive } \\
\text { bact. }\end{array}$ & $1.03 \pm 0.25$ & $0.56 \pm 0.22$ & 0.002 \\
\hline & C16:0 & General bact. & $20.86 \pm 0.98$ & $19.14 \pm 0.71$ & 0.08 \\
\hline & iC17:0 & $\begin{array}{l}\text { Gram positive } \\
\text { bact. }\end{array}$ & $4.50 \pm 0.76$ & $3.31 \pm 0.52$ & 0.03 \\
\hline & $\mathrm{aC} 17: 0$ & $\begin{array}{l}\text { Gram positive } \\
\text { bact. }\end{array}$ & $2.25 \pm 0.32$ & $2.02 \pm 0.29$ & 0.03 \\
\hline & C17:0 & General bact. & $1.57 \pm 0.08$ & $1.29 \pm 0.09$ & 0.007 \\
\hline & C18:0 & General bact. & $3.85 \pm 0.29$ & $3.12 \pm 0.25$ & 0.04 \\
\hline & $\mathrm{C} 24: 1 \omega 9$ & $\begin{array}{l}\text { Gen. } \\
\text { eucaryotes }\end{array}$ & $0.0053 \pm 0.003$ & $0.0017 \pm 0.0013$ & 0.03 \\
\hline
\end{tabular}

well-known resistance of charcoal to biotic decomposition. A similar decrease of the mineralization potential of SOC was observed in soils historically enriched with $\mathrm{BC}$, and the poor degradability of $\mathrm{BC}$ was related to its aromatic structure (Cheng et al., 2008; Liang et al., 2008, 2010). The low degradability of polycyclic aromatic $\mathrm{C}$ for soil biota has been attributed to the large activation energy required for cleavage of aromatic C bonds (Plante et al., 2009). Despite being longer than that of reference soils, average half-lives of $22.2 \pm 9.6$ years (in cropland) and $61.3 \pm 7.3$ years (in forest) for the stable pool of total C of CKS probably did not specifically represent BC. Indeed, the computed half-life seems too short to correspond to the half-life of charcoal that was introduced in soil $>150$ years ago. The decay of the slow-cycling pool, as defined by the double exponential model, is therefore probably mainly related to the decomposition of more stable fraction of the uncharred SOM. Emissions of $\mathrm{CO}_{2}$ from charcoal are likely minor on the timescale of the current incubation experiment (Cheng et al., 2008; Liang et al., 2008; Kuzyakov et al., 2009). With the limited duration of the experiment and number of observations available, inclusion of a third kinetic $\mathrm{C}$ pool was, however, not warranted as this would over-parametrize the model and yield non-robust predictions of decay rates of the least reactive char pool (Bird et al., 2015). 
Since the contribution of aged charcoal to total $\mathrm{CO}_{2}$ emissions are assumed to be low or even negligible at the timescale of our incubation, we tried to estimate the efficiency of uncharred SOM $\mathrm{C}$-mineralization by calculating the rate of $\mathrm{CO}_{2}$ emissions per unit of uncharred SOC, assuming that charcoal's contribution to $\mathrm{CO}_{2}$ emissions is negligible. As a result, there was no systematic effect of CKS on soil $\mathrm{CO}_{2}$ emissions per unit of uncharred SOC. However, $\mathrm{CO}_{2}$ emissions per unit of uncharred SOC correlated strongly with soil $\mathrm{pH}-\mathrm{H}_{2} \mathrm{O}$ (Figure 3), with $r \geq 0.91$ for emission rates throughout the 138 days incubation period. This result attests that soil acidity explains a main part of the variance of soil $\mathrm{CO}_{2}$ emissions once expressed per unit of uncharred SOC, also indicating indirectly that $\mathrm{CO}_{2}$ emissions are governed by the content of uncharred SOM, suggesting no or a limited effect of charcoal on $\mathrm{C}$-mineralization. The large range of soil $\mathrm{pH}$ mainly governed by land use thus at first sight seems to have an overriding control on microbial respiration, surpassing the effect of large amounts of charcoal present in the soil. The linear increase in $\mathrm{CO}_{2}$ emissions per unit of uncharred SOC with $\mathrm{pH}$ is likely due to an increase in microbial abundance. Indeed, the relationship between soil respiration rate at day 68 and PLFA content per unit of $\mathrm{C}$ were linearly related, particularly in croplands $(r=0.97)$ but also in forests $(r=0.82)$ (Figure 4). These results agree with those of Aciego Pietri and Brookes (2008) who found that $\mathrm{pH}$ was a dominant driver of both soil $\mathrm{CO}_{2}$ emissions and total microbial $\mathrm{C}$ biomass along a $\mathrm{pH}$ gradient from 3.7 to 8.3 in UK arable soil. Such a shift in $\mathrm{pH}$ can be expected to dominantly affect the bacterial rather than fungal population (Rousk et al., 2010). However, here the higher soil $\mathrm{pH}$ of croplands $\left(\mathrm{pH}-\mathrm{H}_{2} \mathrm{O} 5.8-8.3\right)$ vs. forests $\left(\mathrm{pH}-\mathrm{H}_{2} \mathrm{O}\right.$ 3.4-5) was accompanied by differences in soil OM quality as well. While we did not further characterize the uncharred OC, the smaller C:N ratio $(P<0.001)$ of cropland $\mathrm{R}$ sites (11.3) than forest sites (15.2) clearly points to a more labile $O M$ in croplands and a faster turnover of SOM. For instance Springob and Kirchmann (2003) found that above a C:N ratio of 15 , German Pleistocene sandy soils quite suddenly contained a large fraction of refractory $\mathrm{OM}$ with a low specific rate of $\mathrm{N}$ supply. Accordingly, a close negative relationship existed between the amount of PLFA per unit of $\mathrm{C}$ and the C:N ratio of SOM (Figure 5), at least at a C:N ratio above about 12. Since a close link also exists between total PLFA and respiration rate (Figure 4), the increase in $\mathrm{CO}_{2}$ emissions with lower a C:N ratio is most likely related to a larger amount of total microbial biomass per unit of uncharred SOC. Regarding microbial efficiency, the $q \mathrm{CO}_{2}$ at day 68 of incubation is similar between CKS and reference soils (Table 2), which suggest that long-term soil charcoal enrichment is predominantly related to the abundance of microorganisms in soil (Figure 4).

Besides the effect of $\mathrm{pH}$ and SOM quality on microbial respiration, Kerré et al. (2017) measured a smaller mineralization of fresh SOM (traced by ${ }^{13} \mathrm{C}$ isotopic signature) when added to a pre-industrial CKS soil. They proposed that an increase of the sorption of dissolved organic carbon (DOC) might explain this decrease, because they measured a preferential adsorption of the DOC rich in aromatics in presence of charcoal in another experiment. This result suggests that beyond the role of $\mathrm{pH}$,
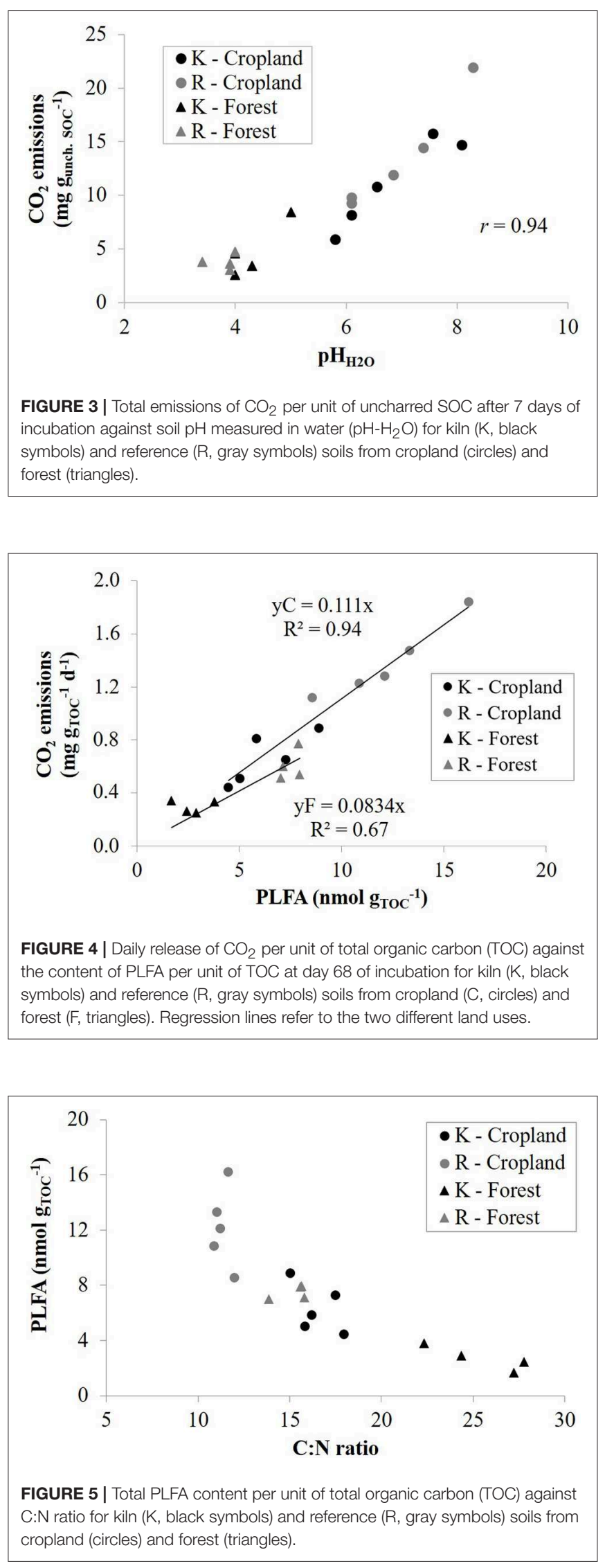
direct interactions of charcoal with the labile, soluble fraction of SOM might influence the mineralization kinetics of labile SOM. To sum up, for the soils of this study developed on a same parent material but affected by distinct land use and levels of charcoal enrichment, the C:N ratio, an indicator of the degradability of SOM (thus integrating the proportion of charcoal and uncharred SOM in soil), was closely related to microbial abundance in soil per unit of total OC. Jointly, microbial abundance was closely and linearly related to the rate of soil respiration, regardless of the presence of charcoal, which agrees with the similar microbial efficiency (expressed by the $\left.q \mathrm{CO}_{2}\right)$ in CKS and adjacent reference soils. It cannot be attested from our data that the effect of aged charcoal on soil respiration and microbial abundance is negligible, nonetheless, most results suggested a minor effect of charcoal, in contrast to the content of uncharred $\mathrm{SOM}$ and $\mathrm{pH}_{\mathrm{H} 2 \mathrm{O}}$ which explain a main fraction of the variance for these variables. Overall, our results agree with a (very) slow turnover of BC in soil regardless of land use and therefore has a limited effect on total soil microbial biomass and activity.

\section{The Effect of Charcoal on Microbial Community Structure}

The presence of charcoal increased the recovery of the C21:0 PC standard, that was added to the soil at the start of the extraction, by $43.6 \%$. This disagrees with the findings of Gomez et al. (2014), who observed a proportional decrease in the recovery of C21:0 PC with increasing applications of biochar. This discrepancy might result from the deep changes in properties of charcoal through $>150$ years of aging in soil (Hardy et al., 2017 b), including a shift from highly hydrophobic to hydrophilic surfaces. This shift is attributed to the creation of a high density of oxygenated functional groups (mainly carboxylic) at the surface of charcoal by oxidation over time (Cheng et al., 2006). Accordingly, Criscuoli et al. (2014) estimated that the soil of centennial CKS was $97.3 \%$ less hydrophobic than an adjacent reference soil. This dramatic decrease in hydrophobicity probably attenuates the affinity of charcoal for dissolved phospholipids. It is also likely that, over time, most sites at the surface of charcoal reactive toward dissolved organic molecules have become saturated. The differing recovery of the C21:0 standard for CKS and $\mathrm{R}$ sites probably does not reflect a likewise impact on extractability of PLFAs, because these are predominantly part of living microbial cells (i.e., in cell membranes), so not as free molecules. Nevertheless, it is clear that a comparison of absolute contents of PLFA between CKS and R soils needs to be considered with care. Assuming a non-selective impact of char presence on the extraction of various PLFAs to their least relative abundances could be compared between different soils.

Both the permutational multivariate analysis of variance and the PCA illustrated that land-use had an overriding control on microbial community structure, surpassing the effect of a vast amount of charcoal present in the soil. The second axis of the PCA discriminated well-between CKS and reference soils (Figure 2), but the distance between CKS and reference soils was much larger for forest than for cropland soils. Further analysis of individual PLFAs highlighted that the shift affected mainly PLFAs linked to $\mathrm{G}+$ and general bacteria. For most of these PLFAs, their proportion on total PLFA biomass was strongly (either positively or negatively) related to soil $\mathrm{pH}_{\mathrm{H} 2 \mathrm{O}}$, concentration of exchangeable $\mathrm{Ca}^{2+}$ and concentration of uncharred SOC (data not shown). In croplands, the effect of CKS was limited, slightly affecting four PLFAs from four distinct microbial groups (actinomycetes, AMF, saprotrophic fungi and general eukaryotes, Table 4). There was no clear relationship between these PLFAs and soil physico-chemical properties. The limited effect of charcoal enrichment in croplands might be caused by the use of fertilizers and liming amendments that standardize soil chemical conditions between CKS and reference soils, whereas in forests the residual effect of charcoal production on several soil properties is still clear (Hardy et al., 2016). Another point to consider is the difference in the depth of sampling between CKS and reference soils in forests. In contrast to croplands, where limiting nutrients are compensated by the application of fertilizers and where SOM is diluted in the plow layer due to frequent tillage, available nutrients accumulate in the forest litter and topsoil as a result of the biological recycling of nutrients, related to uptake by the root system of plants and the restitution by decomposition of forest litter and SOM (Jobbagy and Jackson, 2000). Accordingly, the difference in sampling depth in forests might have accentuated the difference between the charcoal-rich A horizon of CKS soils and the $A_{h}$ horizon of reference soils. Lehmann et al. (2011) concluded that the effect of charcoal on soil biology strongly relies on the group of microorganisms as well as initial soil properties, which were clearly different in both investigated land-uses here. For example, concentrations of available $\mathrm{P}$ and exchangeable $\mathrm{K}$ were not significantly affected by CKS in the plow layer of agricultural soils (Hardy et al., 2017a), whereas both were strongly lowered in the A horizon of forest soils (Hardy et al., 2016). It was also shown that charcoal had an antagonist effects on soil $\mathrm{pH}$ according to land use, with an increase of $\mathrm{pH}$ in very acidic forest soils (Hardy et al., 2016) and a slight but significant decrease of $\mathrm{pH}$ in agricultural soil with an acidity close to neutral. This consideration, combined with the absence of a strong relationship with the concentration of charcoal-C for PLFAs significantly affected by CKS at the scale of the dataset, supports the view that the effect of aged charcoal on microbial community structure is not mainly related to an alteration of the source of organic $\mathrm{C}$ available to soil biota but rather to a modification of the drivers of microbial growth and activity such as the availability of nutrients (Steiner et al., 2009; Blackwell et al., 2010), specific microhabitats in the porosity of charcoal or a shift in pH (Rousk et al., 2010). This is in line with the high resistance to decomposition of the most stable fraction of charcoal that survived oxidation on centennial timescales. Microbial analyzes of terra preta soils have highlighted an important shift in microbial taxonomy from adjacent soils (Kim et al., 2007; Grossman et al., 2010; Jin, 2010). In light of our results, it can be speculated that the introduction of various organic and inorganic inputs involved in the genesis of terra preta soils, and contrasting land use history related to an improved soil fertility of terra preta soils, might have had more influence on the microbial community structure than BC 
itself. A closer look to the abundance of C16:1c11, a biomarker for AMF, stresses the dependence of the effect of charcoal with soil conditions again, as well as the divergence between long-term and short-term effects. In forests, the proportion of AMF was larger in CKS soils $(2.33 \pm 0.49 \%)$ than in adjacent reference soils $(1.97 \pm 0.36 \%)$. This increase might be related to the lower availability of P. Vegetation likely responded by a promoting development of AMF, that aids in plant $\mathrm{P}$ acquisition. A decreased abundance of AMF was observed shortly after the addition of biochar to soil and attributed to a temporary increase in nutrient availability, reducing the need for symbionts (Lehmann et al., 2011). In line with this, the proportion of AMF in CKS soils from croplands, where nutrient availability is much larger, is significantly decreased $(P=0.05$, Table 4). In croplands, the presence of charcoal in the soil might also alter the activity of fungicides, as reported previously for other phytopharmaceuticals such as contact herbicides (Nag et al., 2011). Therefore, a research perspective is to study how the presence of aged charcoal interacts with fungicides and consequently influences the populations of beneficial AMF or pathogen fungi responsible for soil-prone diseases.

\section{CONCLUSIONS}

In this research, preindustrial charcoal kiln sites were used as a natural field experiment to investigate the (very) long-term ( $>150$ years) effect of charcoal on microbial properties of forest and cropland soils, which is an original approach to unravel the long-term fate of biochar in soil. The following conclusions and research perspectives were drawn from the results:

1. Double exponential models are inadequate to capture the long-term dynamics of charcoal-C in soil at the time scale of our experiment, probably because aged charcoal is a negligible source of $\mathrm{CO}_{2}$ emissions from soil. Assuming that charcoal does not contribute significantly to soil respiration, we found that $\mathrm{CO}_{2}$ emissions per unit of uncharred SOC were strongly correlated with soil $\mathrm{pH}$, which supports the idea that charcoal is a minor or negligible driver of soil respiration that is governed mainly by the content and quality of uncharred SOM and soil acidity. These results agree with the long residence time of BC in soil.

2. The C:N ratio appeared to be a good indicator of microbial abundance in soil per unit of TOC, reflecting at the same time the proportion of charcoal and uncharred SOC in soil as well as their respective degradability. Jointly, microbial abundance was closely and linearly related to the rate of soil respiration, regardless of the presence of charcoal, which underlines the similar metabolic quotient in CKS and adjacent reference soils.

3. The higher recovery of standard PLFA (C21:0 PC) added to soil in presence of aged charcoal contrasts with the decreased recovery recorded shortly after addition of biochar to the soil (Gomez et al., 2014). This result underlines that the properties of charcoal evolve dramatically over long periods of time. Accordingly, many long-term effects of charcoal differ from the short-term effects. In the perspective of amending soils with biochar, a long-term vision is therefore critical.
4. In forests, the community structure of CKS soils was clearly different from that of adjacent reference soils, with 10 PLFAs from gram positive and general bacteria significantly affected. Contrastingly, few differences with adjacent reference soils remained in croplands, with only four PLFAs from fungi, gram negative bacteria and actinomycetes significantly affected. In cropland soils that are frequently fertilized and amended, the long-term effect of biochar on soil microbiota is likely to be overwritten by management practices. The strong interaction between the effect of aged charcoal and soil conditions complicates the prediction of the effects that can be expected from an application of biochar to soil. Biochar properties must therefore be regarded together with soil conditions in order to correctly design a successful soil amendment with biochar.

5. The lack of a relationship between individual PLFAs and charcoal-C content supports the idea that the long-term effect of charcoal is mainly related to a modification of soil ecological niche (e.g., related to a shift in $\mathrm{pH}$ or in nutrient availability or the presence of microhabitats in the porous structure of charcoal) rather than to an alteration of the source of organic $\mathrm{C}$ available to biota. This assumption agrees with the low reactivity of aged charcoal in soil.

As a research perspective, new tools in molecular biology might allow the identification of specific microbial groups related to the presence of charcoal, either due to an intrinsic ability to decompose charcoal, or to specific microhabitats provided by charcoal's porosity. We also encourage further studies to decipher the mechanisms by which charcoal may influence microbial groups of high ecological or agronomic importance such as AMF and soil-borne pathogens.

\section{AUTHOR CONTRIBUTIONS}

The work was designed by BH, J-TC, and JD. Field work was carried out by $\mathrm{BH}$ and JD. Soil physico-chemical analyses and the incubation experiment was performed by BH. SS ran PLFA analyses. Data was analyzed by $\mathrm{BH}$ and SS. The manuscript was drafted by $\mathrm{BH}$ and revised by SS, J-TC, and JD.

\section{ACKNOWLEDGMENTS}

We thank Jens Leifeld from the Institute for Sustainability Sciences of the Agroscope of Zürich (Switzerland) for his help in DSC analysis, the technical team of the Earth and Life Institute of UCL for strong support in field work and soil physico-chemical analyses, and the Department of Soil Management of UGent for PLFA extraction. Funds were provided by the General Directorate for Agriculture, Natural Resources and Environment-Public Service of Wallonia and the FSR (Fonds Spéciaux de Recherche) of the Université catholique de Louvain.

\section{SUPPLEMENTARY MATERIAL}

The Supplementary Material for this article can be found online at: https://www.frontiersin.org/articles/10.3389/fenvs. 2019.00110/full\#supplementary-material 


\section{REFERENCES}

Aciego Pietri, J. C., and Brookes, P. C. (2008). Relationships between soil pH and microbial properties in a UK arable soil. Soil Biol. Biochem. 40, 1856-1861. doi: 10.1016/j.soilbio.2008.03.020

Ameloot, N., Sleutel, S., Das, K. C., Kanagaratnam, J., and de Neve, S. (2015). Biochar amendment to soils with contrasting organic matter level: effects on $\mathrm{N}$ mineralization and biological soil properties. GCB Bioenergy 7, 135-144. doi: $10.1111 / \mathrm{gcbb} .12119$

Bird, M. I., Wynn, J. G., Saiz, G., Wurster, C. M., and McBeath, A. (2015). The pyrogenic carbon cycle. Annu. Rev. Earth Planet. Sci. 43, 273-298. doi: 10.1146/annurev-earth-060614-105038

Blackwell, P., Krull, E., Butler, G., Herbert, A., and Solaiman, Z. (2010). Effect of banded biochar on dryland wheat production and fertiliser use in southwestern Australia: an agronomic and economic perspective. Aust. J. Soil Res. 48, 531-545. doi: 10.1071/SR10014

Brodowski, S., Amelung, W., Haumaier, L., Abetz, C., and Zech, W. (2005). Morphological and chemical properties of black carbon in physical soil fractions as revealed by scanning electron microscopy and energy-dispersive X-ray spectroscopy. Geoderma 128, 116-129. doi: 10.1016/j.geoderma.2004.12.019

Bruun, S., Clauson-Kaas, S., Bobulská, L., and Thomsen, I. K. (2014). Carbon dioxide emissions from biochar in soil: role of clay, microorganisms and carbonates. Eur. J. Soil Sci. 65, 52-59. doi: 10.1111/ejss.12073

Cheng, C.-H., Lehmann, J., Thies, J. E., and Burton, S. D. (2008). Stability of black carbon in soils across a climatic gradient. J. Geophys. Res. 113:G02027. doi: 10.1029/2007JG000642

Cheng, C.-H., Lehmann, J., Thies, J. E., Burton, S. D., and Engelhard, M. H. (2006). Oxidation of black carbon by biotic and abiotic processes. Org. Geochem. 37, 1477-1488. doi: 10.1016/j.orggeochem.2006.06.022

Criscuoli, I., Alberti, G., Baronti, S., Favilli, F., Martinez, C., Calzolari, C., et al. (2014). Carbon sequestration and fertility after centennial time scale incorporation of charcoal into soil. PLoS ONE 9:e91114. doi: 10.1371/journal.pone.0091114

Cross, A., and Sohi, S. P. (2011). The priming potential of biochar products in relation to labile carbon contents and soil organic matter status. Soil Biol. Biochem. 43, 2127-2134. doi: 10.1016/j.soilbio.2011.06.016

Fabbri, D., Torri, C., and Spokas, K. A. (2012). Analytical pyrolysis of synthetic chars derived from biomass with potential agronomic application (biochar). Relationships with impacts on microbial carbon dioxide production. J. Anal. Appl. Pyrolysis 93, 77-84. doi: 10.1016/j.jaap.2011.09.012

Glaser, B. (2007). Prehistorically modified soils of central Amazonia: a model for sustainable agriculture in the twenty-first century. Philos. Trans. R. Soc. B Biol. Sci. 362, 187-196. doi: 10.1098/rstb.2006.1978

Glaser, B., Balashov, E., Haumaier, L., Guggenberger, G., and Zech, W. (2000). Black carbon in density fractions of anthropogenic soils of the Brazilian Amazon region. Org. Geochem. 31, 669-678. doi: 10.1016/S0146-6380(00)00044-9

Gomez, J. D., Denef, K., Stewart, C. E., Zheng, J., and Cotrufo, M. F. (2014). Biochar addition rate influences soil microbial abundance and activity in temperate soils. Eur. J. Soil Sci. 65, 28-39. doi: 10.1111/ejss.12097

Grossman, J. M., O’Neill, B. E., Tsai, S. M., Liang, B., Neves, E., Lehmann, J., et al. (2010). Amazonian anthrosols support similar microbial communities that differ distinctly from those extant in adjacent, unmodified soils of the same mineralogy. Microb. Ecol. 60, 192-205. doi: 10.1007/s00248-010-9689-3

Hamer, U., Marschner, B., Brodowski, S., and Amelung, W. (2004). Interactive priming of black carbon and glucose mineralisation. Org. Geochem. 35, 823-830. doi: 10.1016/j.orggeochem.2004.03.003

Hardy, B., Cornelis, J.-T., Houben, D., Lambert, R., and Dufey, J. E. (2016). The effect of pre-industrial charcoal kilns on chemical properties of forest soil of Wallonia, Belgium. Eur. J. Soil Sci. 67, 206-216. doi: 10.1111/ejss. 12324

Hardy, B., Cornelis, J.-T., Houben, D., Leifeld, J., Lambert, R., and Dufey, J. (2017a). Evaluation of the long-term effect of biochar on properties of temperate agricultural soil at pre-industrial charcoal kiln sites in Wallonia, Belgium. Eur. J. Soil Sci. 68, 80-89. doi: 10.1111/ejss.12395

Hardy, B., Leifeld, J., Knicker, H., Dufey, J., Deforce, K., and Cornelis, J.-T. (2017b). Long term change in chemical properties of preindustrial charcoal particles aged in forest and agricultural temperate soil. Org. Geochem. 107, 33-45. doi: 10.1016/j.orggeochem.2017.02.008

Haumaier, L., and Zech, W. (1995). Black carbon-possible source of highly aromatic components of soil humic acids. Org. Geochem. 23, 191-196. doi: 10.1016/0146-6380(95)00003-W

Hilscher, A., and Knicker, H. (2011). Degradation of grass-derived pyrogenic organic material, transport of the residues within a soil column and distribution in soil organic matter fractions during a 28 months microcosm experiment. Org. Geochem. 42, 42-54. doi: 10.1016/j.orggeochem.2010.10.005

IUSS Working Group WRB (2014). World reference base for soil resources 2014. International Soil Classification System for Naming Soils and Creating Legends for Soil Maps. World Soil Resources Reports $\mathrm{N}^{\circ} 106$. Rome: Food and Agriculture Organization of the United Nations.

Jin, H. (2010). Characterization of microbial life colonizing bicohar and biochar-amended soil. (Ph.D. Dissertation). Cornell University, Ithaca, NY, United States.

Jobbagy, E. G., and Jackson, R. B. (2000). The vertical distribution of soil organic carbon and its relation to climate and vegetation. Ecol. Appl. 10, 423-436. doi: 10.1890/1051-0761(2000)010[0423:TVDOSO]2.0.CO;2

Joseph, S. D., Camps-Arbestain, M., Lin, Y., Munroe, P., Chia, C. H., Hook, J., et al. (2010). An investigation into the reactions of biochar in soil. Aust. J. Soil Res. 48, 501-515. doi: 10.1071/SR10009

Kassambara, A., and Mundt, F. (2017). factoextra: Extract and Visualize the Results of Multivariate Data Analyses. R package version 1.0.5. Available online at: https://cran.r-project.org/package=factoextra (accessed June 16, 2019).

Keiluweit, M., Nico, P. S., Johnson, M. G., and Kleber, M. (2010). Dynamic molecular structure of plant biomass-derived black carbon (biochar). Environ. Sci. Technol. 44, 1247-1253. doi: 10.1021/es9031419

Kerré, B., Willaert, B., and Smolders, E. (2017). Lower residue decomposition in historically charcoal-enriched soils is related to increased adsorption of organic matter. Soil Biol. Biochem. 104, 1-7. doi: 10.1016/j.soilbio.2016.10.007

Kim, J. S., Sparovek, G., Longo, R. M., De Melo, W. J., and Crowley, D. (2007). Bacterial diversity of terra preta and pristine forest soil from the Western Amazon. Soil Biol. Biochem. 39, 684-690. doi: 10.1016/j.soilbio.2006. 08.010

Kuzyakov, Y., Subbotina, I., Chen, H., Bogomolova, I., and Xu, X. (2009). Black carbon decomposition and incorporation into soil microbial biomass estimated by 14C labeling. Soil Biol. Biochem. 41, 210-219. doi: 10.1016/j.soilbio.2008.10.016

Lakanen, E., and Erviö, R. (1971). A comparison of eight extractans for the determination of plant available micronutrients in soils. Acta Agral. Fenn. $123,223-232$.

Lehmann, J., Gaunt, J., and Rondon, M. (2006). Bio-char sequestration in terrestrial ecosystems - a review. Mitig. Adapt. Strateg. Glob. Chang. 11, 395-419. doi: 10.1007/s11027-005-9006-5

Lehmann, J., Rillig, M. C., Thies, J. E., Masiello, C. A., Hockaday, W. C., and Crowley, D. (2011). Biochar effects on soil biota - a review. Soil Biol. Biochem. 43, 1812-1836. doi: 10.1016/j.soilbio.2011.04.022

Leifeld, J. (2007). Thermal stability of black carbon characterised by oxidative differential scanning calorimetry. Org. Geochem. 38, 112-127. doi: 10.1016/j.orggeochem.2006.08.004

Liang, B., Lehmann, J., Sohi, S. P., Thies, J. E., O’Neill, B., Trujillo, L., et al. (2010). Black carbon affects the cycling of non-black carbon in soil. Org. Geochem. 41, 206-213. doi: 10.1016/j.orggeochem.2009.09.007

Liang, B., Lehmann, J., Solomon, D., Sohi, S., Thies, J. E., Skjemstad, J. O., et al. (2008). Stability of biomass-derived black carbon in soils. Geochim. Cosmochim. Acta 72, 6069-6078. doi: 10.1016/j.gca.2008.09.028

Maestrini, B., Nannipieri, P., and Abiven, S. (2014). A meta-analysis on pyrogenic organic matter induced priming effect. GCB Bioenergy 7, 577-590. doi: $10.1111 /$ gcbb.12194

Metson, A. J. (1956). Methods of Chemical Analysis for Soil Survey Samples. Bulletin: New Zealand Soil Bureau.

Nag, S. K., Kookana, R., Smith, L., Krull, E., Macdonald, L. M., and Gill, G. (2011). Poor efficacy of herbicides in biochar-amended soils as affected by their chemistry and mode of action. Chemosphere 84, 1572-1577. doi: 10.1016/j.chemosphere.2011.05.052

Oksanen, J., Blanchet, F., Guillaume Friendly, M., Kindt, R., Legendre, P., McGlinn, D., et al. (2019). vegan: Community Ecology Package. R package 
version 2.5-4. Available online at: https://cran.r-project.org/package=vegan (accessed June 16, 2019).

Plante, A. F., Fernández, J. M., and Leifeld, J. (2009). Application of thermal analysis techniques in soil science. Geoderma 153, 1-10. doi: 10.1016/j.geoderma.2009.08.016

R Core Team (2012). R: A Language and Environment for Statistical Computing. Vienna.

Rodella, A. A., and Saboya, L. V. (1999). Calibration for conductimetric determination of carbon dioxide. Soil Biol. Biochem. 31, 2059-2060. doi: 10.1016/S0038-0717(99)00046-2

Rousk, J., Baath, E., Brookes, P. C., Lauber, C. L., Lozupone, C., Caporaso, J. G., et al. (2010). Soil bacterial and fungal communities across a $\mathrm{pH}$ gradient in an arable soil. ISME J. 4, 1340-1351. doi: 10.1038/ismej.2010.58

Sagrilo, E., Jeffery, S., Hoffland, E., and Kuyper, T. W. (2014). Emission of CO2 from biochar-amended soils and implications for soil organic carbon. GCB Bioenergy 7, 1294-1304. doi: 10.1111/gcbb.12234

Sherrod, L. A., Dunn, G., Peterson, G. A., and Kolberg, R. L. (2002). Inorganic carbon analysis by modified pressure-calcimeter method. Soil Sci. Soc. Am. J. 66, 299-305. doi: 10.2136/sssaj2002.2990

Singh, N., Abiven, S., Torn, M. S., and Schmidt, M. W. I. (2012). Fire-derived organic carbon in soil turns over on a centennial scale. Biogeosciences 9, 2847-2857. doi: 10.5194/bg-9-2847-2012

Sleutel, S., Bouckaert, L., Buchan, D., Van Loo, D., Cornelis, W. M., and Sanga, H. G. (2012). Manipulation of the soil pore and microbial community structure in soil mesocosm incubation studies. Soil Biol. Biochem. 45, 40-48. doi: 10.1016/j.soilbio.2011.09.016

Springob, G., and Kirchmann, H. (2003). Bulk soil C to N ratio as a simple measure of net $\mathrm{N}$ mineralization from stabilized soil organic matter in sandy arable soils. Soil Biol. Biochem. 35, 629-632. doi: 10.1016/S0038-0717(03)00052-X
Steiner, C., Garcia, M., and Zech, W. (2009). "Effects of charcoal as slow release nutrient carrier on N-P-K dynamics and soil microbial population: pot experiments with ferralsol substrate," in Amazonian Dark Earths: Wim Sombroek's Vision, eds W. I. Woods, W. G. Teixeira, J. Lehmann, C. Steiner, A. WinklerPrins, and L. Rebellato (Dordrecht: Springer), 325-338. doi: 10.1007/978-1-4020-9031-8_17

Wardle, D., a, Nilsson, M.-C., and Zackrisson, O. (2008). Fire-derived charcoal causes loss of forest humus. Science. 320:629. doi: 10.1126/science. 1154960

Wiedemeier, D. B., Abiven, S., Hockaday, W. C., Keiluweit, M., Kleber, M., Masiello, C. A., et al. (2015). Aromaticity and degree of aromatic condensation of char. Org. Geochem. 78, 135-143. doi: 10.1016/j.orggeochem.2014. 10.002

Zimmerman, A. R., Gao, B., and Ahn, M.-Y. (2011). Positive and negative carbon mineralization priming effects among a variety of biocharamended soils. Soil Biol. Biochem. 43, 1169-1179. doi: 10.1016/j.soilbio.201 1.02 .005

Conflict of Interest Statement: The authors declare that the research was conducted in the absence of any commercial or financial relationships that could be construed as a potential conflict of interest.

Copyright (c) 2019 Hardy, Sleutel, Dufey and Cornelis. This is an open-access article distributed under the terms of the Creative Commons Attribution License (CC BY). The use, distribution or reproduction in other forums is permitted, provided the original author(s) and the copyright owner(s) are credited and that the original publication in this journal is cited, in accordance with accepted academic practice. No use, distribution or reproduction is permitted which does not comply with these terms. 